\title{
Neoproterozoic amphibolite-facies metamorphism of Douling complex at the northern margin of the Yangtze Craton
}

Yu He, Yuanbao Wu, Yuje Zhao, GuAngyan Zhou

\author{
China University of Geosciences (Wuhan)
}

It has long been a subject of long debate about the Neoproterozoic tectonic setting of the continental margin of the Yangtze Craton. The Douling complex, which represents the oldest crystalline basement, records the Neoproterozoic metamorphism and can thus provide important constraints on the tectonic evolution of the Yangtze Craton. In this study, we conducted an integrated study of petrography, zircon $\mathrm{U}-\mathrm{Pb}$ ages and $\mathrm{Hf}-\mathrm{O}$ isotopic compositions for garnet amphibolite and gneiss in the Douling complex. Zircon grains from the gneiss mostly reveal corerim structures. The cores display oscillatory zoning, high $\mathrm{Th} / \mathrm{U}$ and ${ }^{176} \mathrm{Lu} /{ }^{177} \mathrm{Hf}$ ratios, high trace element contents, as well as HREE enriched patterns, consistent with a magmatic origin. They yielded a weighted mean ${ }^{206} \mathrm{~Pb} /{ }^{238} \mathrm{U}$ age of $868 \pm 9$ Ma, which is taken as the protolith age of the gneiss. The cores have high $\varepsilon_{\mathrm{Hf}}(\mathrm{t})$ values of 7.015.6 and young single-stage $\mathrm{Hf}$ model ages of ca. $1150-800 \mathrm{Ma}$, indicating prompt reworking of juvenile crust during their fromation. The zircon rims in gneiss and zircon crystals from two amphibolites perform weakly zoned patterns, low $\mathrm{Th} / \mathrm{U}$ and ${ }^{176} \mathrm{Lu} /{ }^{177} \mathrm{Hf}$ ratios, high $\delta^{18} \mathrm{O}$ values, pronounced negative Eu anomalies and flat HREE profiles, suggeating they formed coeval with garnet and plagioclase under amphibolite-facies conditions. Metamorphic zircon in three samples yield a weighted mean age of $817 \pm 4 \mathrm{Ma}$, which is taken as the best estimated age of the amphibolite-facies metamorphism. Phase equilibrium modeling and conventional geothermobarometry define peak P-T conditions of 9-10 kbar and $670 \sim 690^{\circ} \mathrm{C}$, and record a clockwise P-T path. Considering the widespread magmatism in the Yangtze craton, we propose that the Douling complex exprienced tectnoic transformation related to oceanic subduction, and then rapid exhumation in responce to extensional orogenic collapse. 